\title{
Impact of elevated temperature on rice productivity: A case of Lalitpur, Nepal
}

\author{
Ambika Ghimire $^{1 *}$, Yubak Dhoj G.C ${ }^{1}$ and Binod Baniya ${ }^{2}$ \\ ${ }^{1}$ Central Department of Environment Science, Tribhuvan University, Kathmandu \\ ${ }^{2}$ Department of Agriculture, Ministry of Agricultural Development, Government of Nepal, Kathmandu \\ ${ }^{3}$ Department of Environment Science, Patan Multiple Campus, Tribhuvan University, Kathmandu
}

\begin{abstract}
Rice (Oryza sativa L.) is the second most important crop in the world after wheat and also the most important crop in Nepal. The production of rice is influenced by various biotic and abiotic factors. Temperature is the major constraint for the crop yield. The present experiment was conducted to study the impact of temperature on straw and crop productivity from June to October 2014. The experiment was conducted under temperature control chamber, in which temperature was elevated from the ambient level by $2^{\circ} \mathrm{C}$ and $3^{\circ} \mathrm{C}$ for the entire crop growth period. Grain and straw yield was measured using electronic weighing machine. Maturity of grain was 10 and 7 days earlier at elevated temperature by $3^{\circ} \mathrm{C}$ and $2^{\circ} \mathrm{C}$ respectively. Under similar condition of water depth, plant spacing, rice variety and soil nutrient, rise in temperature up to $2^{\circ} \mathrm{C}$ is favorable for rice straw yield and crop productivity. Yield loss under elevated temperature by $3^{\circ} \mathrm{C}$ is due to floret sterility. Further research on temperature resistance rice variety is necessary.
\end{abstract}

Key words: Production, Straw yield, Temperature

\section{Introduction}

Agriculture largely depends on climatic parameters like rainfall, humidity and temperature. Agriculture, particularly rain-fed, is extremely sensitive to climate change (R amay et al., 2011). A temperature increase of more than $2.5^{\circ}$ Celsius will severely affect crop production in Nepal because of increased evaporation and evapo-transpiration leading to increased heat stress on the soil and crops (Regmi, 2007).

Rice (Oryza sativa L.) is the second most important crop in the world after wheat and is also the most important crop in Nepal. It is grown on about 145 million hectares in the world with annual production of 518 million tons (FAO, 2004).

Rice is a prime food crop and meets more than $50 \%$ of the total calories requirement of the Nepalese people with daily consumption of about $262 \mathrm{gm} / \mathrm{capita}$ (NARC, 2007; MoAD, 2013). It contributes about $20.75 \%$ in Agriculture Gross Domestic Product and 6.93\% of GDP (MoAD, 2012). Agriculture in Nepal is more vulnerable to climate change because $64 \%$ of the cultivated land is rain-fed and two third of the population has agriculture based livelihood (FAO, 2004; NAPA, 2010).

Rice production is affected by temperature and precipitation (Malla, 2008). Climate change directly affect on precipitation and

*Corresponding author, email address: ambika.ghimire45@gmail.com temperature, with rise in temperatures leading to water deficit, changing soil moisture status, and pest and disease incidence (Chinvanno, 2010). As climate change will have major impact on water availability; rice production will have to bear significant brunt of this change (Isendahl \& Schmidt, 2006). Water shortage during periods of low rainfall affects the vegetative growth rate and grain yield of rice (Tao et al., 2006). According to Inter governmental Panel on Climate Change (IPCC) some risks of climate change are considerable at 1 or $2^{\circ} \mathrm{C}$ above preindustrial levels. Global climate change risks are high to very high with global mean temperature increase of $4^{\circ} \mathrm{C}$ or more compared to the pre-industrial levels in all regions for concern, and include severe and widespread impacts on unique and threatened systems, substantial species extinction, large risks to global and regional food security and the combination of high temperature and humidity compromising normal human activities, including growing food or working outdoors in some areas for parts of the year (IPCC, 2014). Increasing temperature or hotter night temperatures can cause increased spikelet sterility in rice and reduced grain yield (Wassmann \& Dobermann, 2007). High temperature damage photosynthetic membranes (thylakoids) and can cause chlorophyll loss, decrease in leaf photosynthetic rate, increased embryo abortion, lower grain number, and decreased grain filling duration and rates, thus may resulting in lower grain yield (Sultan et al., 2013). 
Numbers of research works on climate change impact on rice yield have been conducted, but the control experiment focusing on impact of elevated temperature on straw and crop yield is limited. The present study was conducted to understand temperature relationship with straw and crop productivity which will be helpful to the far mers, agronomist, scientist, decision makers and planners.

\section{Materials and Methods}

Experiment was conducted from July to October, 2014. During the experimental period, the average maximum temperature of $28.85,28.40,27.14$ and $24.5^{\circ} \mathrm{C}$ and minimum temperature of 15.64 , $20.60,21.45$ and $15.13^{\circ} \mathrm{C}$ was recorded. Similarly, the total rainfall received was $782.2 \mathrm{~mm}$ during the growing period of rice, i.e., June to October.

\section{Experimental details for varied temperature}

The experiment was conducted under temperature control chamber, in which temperature was elevated from the ambient level by $2^{0} \mathrm{C}$ and $3^{\circ} \mathrm{C}$ for the entire crop growth period. Experiment was conducted on control environment at far mer's field in Chapagaun Lalitpur, during June to October 2014. The altitude of the site is about 1463 meter from the sea level. Geographically, it is located at $27^{\circ} 355^{\prime} 34.6^{\prime \prime}$ North latitude and $85^{\circ} 19^{\prime} 32.2^{\prime \prime}$ East longitudes. Paddy was grown at $0.27 \%$ nitrogen, $215.3 \mathrm{~kg} / \mathrm{ha}$ phosphorous, $256.03 \mathrm{~kg} /$ ha potassium and $5.51 \%$ organic matter. Addition of inorganic fertilizer throughout experiment period was avoided.

The experimental area was divided into three plots of $4 \mathrm{~m} \times 4 \mathrm{~m}$ size maintaining a buffer of $0.5 \mathrm{~m}$ between adjacent plots. There were three treatments (one ambient condition and two elevated temperatures) and each treatment consists of four replicates (Fig. 1). Each replicated plot consist an area of $2 \mathrm{~m} \times 2 \mathrm{~m}$. The local high yielding rice variety namely 'Khumal-4, Local Mangsuli' was considered as the experimental crop for the study. Water depth of $6 \mathrm{~cm}$ was maintained throughout the experimental period.
The rice seedlings were transplanted on $2^{\text {nd }} J u l y, 2014$ with $7 \mathrm{~cm}$ $\mathrm{x} 6 \mathrm{~cm}$ space. The date of maturity of each treatment was recorded i.e. $5^{\text {th }}$ October for $3^{\circ} \mathrm{C}$ temperature elevation, $1^{\text {st }}$ November for $2^{\circ} \mathrm{C}$ elevation and $4^{\text {th }}$ November for ambient temperature condition.

\section{Temperature measurement}

Temperature in the experimental plot/chamber was elevated by constructing open top chamber made up of plastic and bamboo. Difference in temperature was obtained by differencing in percentage coverage of plastic in chamber. Thermometer was used for the measurement of temperature. Temperature in the experimental chamber was recorded thrice a day at the inter val of six hours from July to October, 2014 (Table 1). The ambient condition temperature data of Khumaltar, Lalitpur station (Table 2) was used for the analysis.

Table 1 Average maximum temperature $\left({ }^{\circ} \mathrm{C}\right)$ in experimental chamber

\begin{tabular}{lrr}
\hline \multicolumn{1}{c}{ Months } & $\mathbf{1}^{\text {st }}$ chamber & $\mathbf{2}^{\text {nd }}$ chamber \\
\hline July & 31.2 & 31.95 \\
August & 30.40 & 31.4 \\
September & 29.8 & 29.2 \\
October & 26.1 & 27.8 \\
Average maximum temperature & 29.37 & 30.08 \\
during experiment & & \\
\hline
\end{tabular}

Table 2 Ambient temperature $\left({ }^{\circ} \mathrm{C}\right)$ condition in Khumaltar station

\begin{tabular}{lcccc}
\hline Months & Minimum & Maximum & Average & $\begin{array}{c}\text { Average maximum } \\
\text { temperature during } \\
\text { experiment }\left({ }^{\circ} \mathrm{C}\right)\end{array}$ \\
\hline July & 15.64 & 28.85 & 22.24 & 27.22 \\
August & 20.60 & 28.40 & 24.5 & \\
September & 21.45 & 27.14 & 24.29 & \\
October & 15.13 & 24.50 & 19.81 & \\
\hline
\end{tabular}

\section{Grain and straw yield measurement}

After harvesting of crop from the field, grain was dried, threshed and again sun-dried. Grain was weighed at 10.1\% moisture content

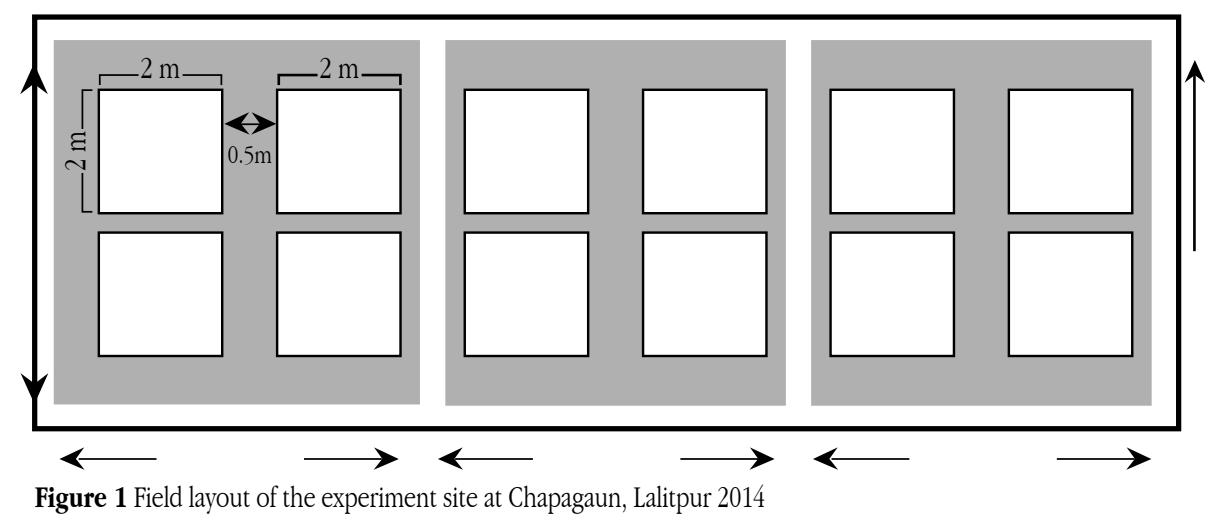


with the help of digital weighing machine. Grain moisture was measured at the laborator y of Soil Science Division, National Agriculture Research Council (NARC), Lalitpur using moisture and temperature meter.

Paddy was harvested in October. After removing grain, straw was weighed within six hours, with the help of electronic weighing machine (model GTP). Straw from each treatment was weighed separately.

\section{Data Analysis}

Data on crop productivity and straw yield were collected from the experimental plots. All the collected data was refined and entered in MS-Excel. Further, the data were analyzed through MS-Excel 2007, with the suitable charts, graphs, etc. Straw and grain yield was calculated in percentage coverage.

\section{Results and Discussion}

Temperature relation with straw and grain yield

Productivity of rice under elevated temperature along with ambient temperature is shown in Figure 2. Results revealed that productivity of crop was influenced by elevated temperature.

Grain yield was found to be increased by $11 \%$ and $3.5 \%$ at elevated temperature by $2^{\circ} \mathrm{C}$ and $3^{\circ} \mathrm{C}$ respectively than the ambient condition under unchecked weed (Fig. 2). At $3{ }^{0} \mathrm{C}$ temperature elevation, ripening of grain was earlier with poor grain filling ( $\mathrm{F}$ ig. 2). Increasing temperature can cause increased spik elet sterility in rice and reduce grain yield (Wassmann \& Dobermann, 2007). This might be the reason behind decrease in production when temperature was elevated by $3^{\circ} \mathrm{C}$. Similar results were reported by Rai et al. (2009) and Malla (2008). High temperature damage photosynthetic membranes (thylakoids) and cause chlorophyll loss, decrease leaf photosynthetic rate, increase embryo abortion, lower grain number, and decrease grain filling duration and rates, thus result in lower grain yield (Sultan et al., 2013). Maturity of grain was 10 and 7 days earlier at $3^{\circ} \mathrm{C}$ and $2^{\circ} \mathrm{C}$ elevated temperature respectively than the ambient condition (Table 1 ).

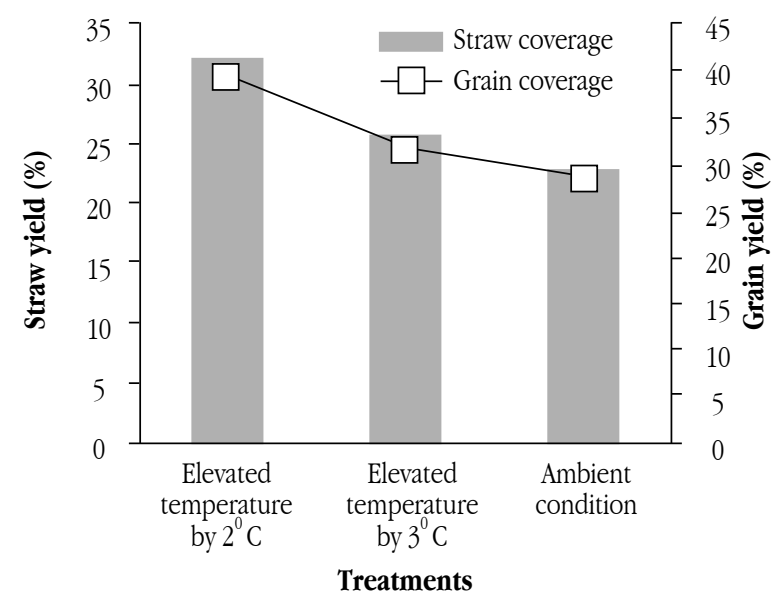

Figure 2 Temperature relation with straw and grain yield (\% coverage)
At elevated temperature by $2{ }^{\circ} \mathrm{C}$ and $3{ }^{\circ} \mathrm{C}$, the straw yield was respectively $11.6 \%$ and $3.7 \%$ higher than the ambient temperature (Fig. 2). There was $8 \%$ increased in straw yield at $2{ }^{\circ} \mathrm{C}$ elevated temperature in comparison to $3^{\circ} \mathrm{C}$ temperature elevation. High temperature damage photosynthetic membranes (thylakoids) and cause chlorophyll loss and decrease leaf photosynthetic rate. At the molecular level, high temperature adversely affect cell metabolism and cause changes in the pattern of protein synthesis (Sultan et al., 2013). This might be the reason behind reduction in straw yield at $3^{\circ} \mathrm{C}$ elevated temperature. crop productivity in long run. The study suggests further researches on temperature resistance rice variety.

\section{Conclusion}

The present study reveals that that there is increase in rice production at elevated temperature by $2^{\circ} \mathrm{C}$ and $3^{\circ} \mathrm{C}$ in comparision to the ambient condition. But, there is reduction in grain yield at elevated temperature by $3^{\circ} \mathrm{C}$ in compared to the temperature elevation by $2{ }^{\circ} \mathrm{C}$. This reduction in grain yield may be due to spikelet sterility at flowering stage. For the Khumal-4 rice variety increase in temperature by $2^{0} \mathrm{C}$ favored the crop production. This experiment shows elevated temperature has negative impact on straw and crop productivity in long run. The study suggests further researches on temperature resistance rice variety.

\section{Acknowledgements}

The authors are grateful to the Central Department of Environment Science, Strengthening Disaster Risk Management in Academia (SDRMA) project for providing opportunity and financial support; and seed science and technology division, National Agriculture Research Council (NARC), Khumaltar for laborator y facility for grain-moisture measurement. The authors are thankful to Ghanashyam Malla, Senior scientist of NARC for his inspirational guidance and valuable suggestions to make this study success.

\section{References}

Chinvanno, S. (2010). Climate change adaptation as a development strategy: A major challanges for Southeast Asian Countries. Southeast Asia START Regional Center, Chulalongkorn University, Thailand.

Malla, G. (2008). Climate change and its impact on Nepalese agriculture. The Journal of Agriculture and Environment, 9, $62-71$

MoAD (2012). Stastical information on Nepalese agriculture(2011/2012). Government of Nepal, Ministry of Agriculture Development, Agri-Business Promotion and Stastical Division (Stastistics Section). Kathmandu.

MoAD (2013). Statiscal Information on Nepalese Agriculrure (2012/13). Agri-Business Promotion and Statistical Divison. Ministry of Agricultural Development. Kathmandu. 
NAPA (2010). National Adaptation Programme of Action. Ministry of Environment, Government of Nepal, Kathmandu.

NARC (2007). Research highlights: 2002/03-2006/07. Communication, publication and documentation division, Nepal Agricultural Research Council(NARC). Khumaltar, Lalitpur.

Rai, Y. K., Ale, B. B., \& Alam, J. (2009). Impact assessment of climate change on paddy yield: A case study of Nepal Agriculture Research Council (NARC), Tarahara, Nepal. Journal of the Institute of Engineering, 8, 147-167.

Ramay, S., Munawar, Z., \& Ahmad, M. (2011). Climate change and food security in the HKH region., (pp. 18-19). Kathmandu.
Regmi, H. R. (2007). Effect of unusual weather on cereal crops production and household food security. The Journal of Agriculture and Environment, 8, 20-29.

Sultan, S., Asaduzzamana, M., \& Zabair, H. M. (2013). Effect of temperature on wheat-ryegrass seedlings intereferance. Universal Journal of Agricultural Research, 1(2), 38-40.

Tao, H., Brueck, H., Dittert, K., Kreye, C., Lin, S., \& Sattelmacher, B. (2006). Growth and yield formation for rice(Oryza sativa $L$.) in the watersaving ground cover rice production system (GCRPS). Field Crops Research, 95(1), 1-12.

Wassmann, R., \& Dobermann, A. (2007). Climate change adaptation through rice production in regions with high poverty levels. Journal of ICRISAT Agricultural Research, 4(1), 1-24. 